\title{
A Comparative Study on Behavior of RC Columns Strengthened by CFRP and Steel Jacket
}

\author{
Rawaa S. Ibraheem ${ }^{1, a^{*}}$ and Alaa H. Al-Zuhairi ${ }^{1, b}$ \\ ${ }^{1}$ Department of Civil Engineering, University of Baghdad, Baghdad, Iraq. \\ arawaasaadi95@gmail.com, balaalwn@coeng.uobaghdad.edu.iq
}

\begin{abstract}
This paper studies the behavior of axially loaded RC columns which are confined with carbon fiber reinforced polymers' sheet (CFRP) and steel jackets (SJ). The study is based on twelve axially loaded RC columns tested up to failure. It is divided into three schemes based on its strengthening type; each scheme has four columns. The main parameters in this study were the compressive strength of the concrete and steel reinforcement ratio. Furthermore, the results of the experimental test showed a substantial enhancement in the column's load-carrying capacity. When compared to the original columns, the CFRP sheet had a significant effect on improving the ductility of the column by increasing the axial deformation by about 59.2 to $95.7 \%$. On the other hand, the SJ contributed mostly to the column load-carrying capacity, which increased the capacity of RC concrete from 75 to $107 \%$; because of its composite action comparing with the CFRP sheet action in which unidirectional lateral confinement is provided. Both methods produced completely different failure modes. The columns strengthened with CFRP sheet failed by rupture occurring in the sheet fibers. The strengthened with SJ failed due to the buckling that occurred in the steel angles due to the direct contact with the head of the column, and crushing in the concrete has occurred.
\end{abstract}

Keywords: Strengthening; steel jacket; carbon fiber reinforced polymer; composite column.

\section{Introduction}

Columns are compression members and are the most important structural members. Their failure can lead to a total collapse of the building. Causes of deterioration could range from the use of poor quality construction materials, defective structural practices, or increased demand in the loading of structure, due to natural causes, such as earthquakes, tornados, or human causes, for example, road traffic accidents [1]. Most columns are designed with a rectangle or square cross-section for architectural requirements [2,3]. The use of composite materials for strengthening and rehabilitating deficient RC systems has increased worldwide in the past few years. The CFRP has been widely used in externally strengthening for different structural members such as beams, columns, and slabs [4]. This application gained popularity due to the lightweight, corrosion-resistant, and tensile strength of FRP materials which was used in the seventies in the space industry. The CFRP jacket provides the $\mathrm{RC}$ columns with passive confinement and is stressed only when an additional axial load is applied to a column that causes dilation. The degree of confinement and the overall strength enhancement of confined concrete is influenced by several factors: fiber modulus, fiber thickness, fiber rupture strain, column size, and column shape (circular, square, or rectangular) [5]. In addition to the FRP method, a steel jacket can improve the load-carrying capacity of the RC column. This is achieved by producing a lateral confinement system with four steel angels. Said angles are connected to the concrete using adhesive material with discontinuous strips welded transversely at a specific spacing.

The investigation of carbon fiber reinforced polymer was thoroughly examined by many researchers [6-9]. They studied the effect of corner roundness, the column height, the cross-section shape, the number of layers, and the method of wrapping (partially or complete) on the strength and ductility of the RC column. They found that the strength enhanced as the rounding of the corner radius increased until it reached the circular section and increased as the thickness of the CFRP increased. Moreover, the ultimate strength and ductility have decreased as the slenderness ratio ( $\ell$ column height/h long side of column section) Increased. Others [10-13] investigate the effect of steel jackets on the behavior of RC columns with some parameters controlled such as the size of angels and battens, 
the spacing between battens, the shape of steel section used. They concluded that the decrease in spacing between battens and increase in the size of vertical angle section enhanced the behavior of strengthened concrete column.

\section{Experimental Test}

Work Plan: Laboratory work is accomplished by casting 12 columns divided into four groups and three schemes, the groups divided according to two parameters; concrete compressive strength (24.2 and $31.7 \mathrm{MPa}$ ) and reinforcement steel ratio $(1.4$ and $2 \%)$. According to these parameters, there are three columns of different types of strengthening (without strengthening as a reference specimen, strengthening with CFRP, and strengthening with steel jacket).

Details of Tested Specimen: All the specimens were designed by a cross-section of $(150 \mathrm{~mm} \times 150$ $\mathrm{mm})$ with a height of $1000 \mathrm{~mm}$. These dimensions were selected to satisfy the requirement of ACI 318-19 [14] to the slenderness ratio for the short column. Two different longitudinal steel reinforcements were used $(4 \phi 10 \mathrm{~mm}$ and $4 \phi 12 \mathrm{~mm})$ with a tie of $(\phi 8 \mathrm{~mm})$ provided at $80 \mathrm{~mm}$ spacing at the column ends and $107 \mathrm{~mm}$ at the middle part of the column. The column is detailed as shown in Figure 1. The column specimens were concentrically loaded until failure using the compression machine shown in Figure 2. Table 1 shows the details of all tested column specimens through this study. one CFRP layer was applied by wrapping the column with an overlap of $120 \mathrm{~mm}$. The application of the CFRP layer was such that the direction of carbon fibers is perpendicular to the column's longitudinal axis, as shown in Figure 1(b). The steel jacket was executed using four steel angle sections $(\mathrm{L} 40 \times 40 \times 4) \mathrm{mm}$ erected at the corners of the column specimen using the adhesive material: Nitomortar TC-2000 and steel battens of $(40 \times 4) \mathrm{mm}$ spaced at $240 \mathrm{~mm} \mathrm{c} / \mathrm{c}$ in all column specimens.

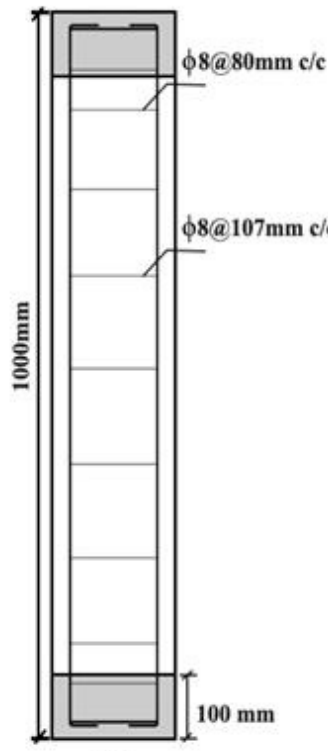

(a)

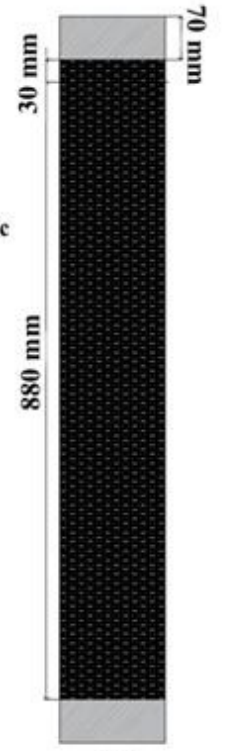

(b)

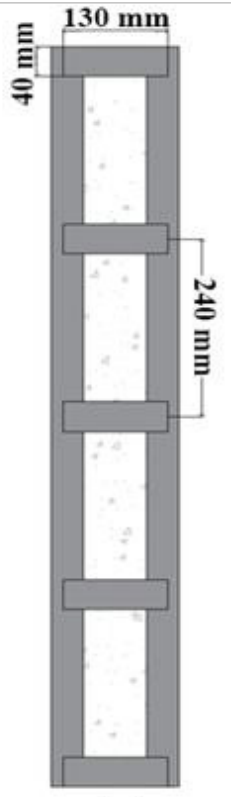

(c)

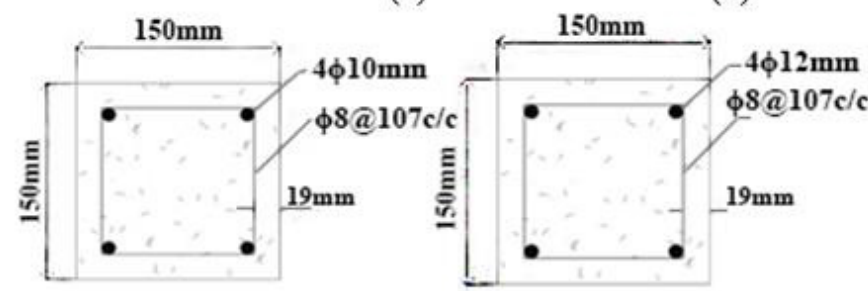

(d)

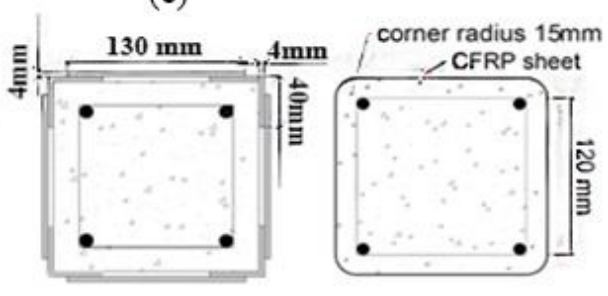

(e)

Figure 1. (a) Reference columns details, (b) Column strengthened with CFRP, (c) Column strengthened with SJ (d) Column sections (e) Details of strengthening techniques. 
Table1. Details of all specimen tested.

\begin{tabular}{|c|c|c|c|c|}
\hline Specimen & Type of strengthening & $\mathbf{f}_{\mathbf{c}}^{\prime}(\mathbf{M P a})$ & Longitudinal reinforcement & $\boldsymbol{\rho}_{\mathbf{s}}$ \\
\hline $24 \mathrm{CN} 1$ & Non & 24.2 & $4 \phi 10$ & $1.4 \%$ \\
\hline $24 \mathrm{CC} 1$ & CFRP & 24.2 & $4 \phi 10$ & $1.4 \%$ \\
\hline $24 \mathrm{CS} 1$ & SJ & 24.2 & $4 \phi 10$ & $1.4 \%$ \\
\hline $32 \mathrm{CN} 1$ & Non & 31.7 & $4 \phi 10$ & $1.4 \%$ \\
\hline $32 \mathrm{CC} 1$ & CFRP & 31.7 & $4 \phi 10$ & $1.4 \%$ \\
\hline $32 \mathrm{CS} 1$ & SJ & 31.7 & $4 \phi 10$ & $1.4 \%$ \\
\hline $24 \mathrm{CN} 2$ & Non & 24.2 & $4 \phi 12$ & $2 \%$ \\
\hline $24 \mathrm{CC} 2$ & CFRP & 24.2 & $4 \phi 12$ & $2 \%$ \\
\hline $24 \mathrm{CS} 2$ & SJ & 24.2 & $4 \phi 12$ & $2 \%$ \\
\hline $32 \mathrm{CN} 2$ & Non & 31.7 & $4 \phi 12$ & $2 \%$ \\
\hline $32 \mathrm{CC} 2$ & CFRP & 31.7 & $4 \phi 12$ & $2 \%$ \\
\hline $32 \mathrm{CS} 2$ & SJ & 31.7 & $4 \phi 12$ & $2 \%$ \\
\hline
\end{tabular}

Material Properties: Ordinary Portland cement (OPC) Type I (trademark: Mass Group Holding) was used to cast all column specimens. The results of chemical and physical properties for a cement sample tested in the Building Research Center of the Ministry of Construction, Housing, Municipalities, and Public Works are shown in Table 2 and Table 3. The results show that the cement sample conforms with IQS NO.5 (1984) [15]. The gradient of the sand used in the concrete mixture was appropriate according to the specification IQS NO.45 (1980)[16]. The crushed gravel was used with a maximum size of $12.5 \mathrm{~mm}$. The gradient of nominal aggregate was accepted according to IQS NO.45 (1980) [16].

Table 2. Chemical composition of the cement-based on Iraqi Standard No. (5) of 1984.

\begin{tabular}{|c|c|c|c|c|c|}
\hline Chemical Formula & L.O.I & SO3 & MgO & L.S.F & I.R \\
\hline Results of Test & 2.48 & 2.49 & 2.54 & 0.95 & 0.55 \\
\hline Limit of IQS No.5:1984 & Max. 4 & Max. 8 & Max.5 & $0.66-1.02$ & Max.1.5 \\
\hline
\end{tabular}

Table 3. Physical properties of cement-based on Iraqi Standard No. (5) of 1984.

\begin{tabular}{|c|c|c|c|}
\hline \multicolumn{2}{|c|}{ Test } & Result & Limits \\
\hline \multicolumn{2}{|c|}{ Fineness $\mathrm{cm}^{2} / \mathrm{gm}$} & 3925 & At least 2300 \\
\hline \multirow{3}{*}{ Setting Time } & Initial & $150 \mathrm{~min}$. & At least 45 \\
\cline { 2 - 4 } & Final & 4.30 hour & Not exceed 10 \\
\hline $\begin{array}{c}\text { Compressive } \\
\text { Strength }\end{array}$ & 3 days & 18 & At least 15 \\
\cline { 2 - 4 } & 7 days & 27 & At least 23 \\
\hline
\end{tabular}

The test results of sand and gravel are shown in Table 4 and Table 5. The superplasticizer (Flocrete W52) from the DCP company was used to reduce the water content and improve the workability.

Table 4. Properties of fine aggregate.

\begin{tabular}{|c|c|c|}
\hline Characteristic & Value & IQS 45:1981 \\
\hline Specific Gravity & 2.75 & ----- \\
\hline $\mathrm{SO}_{3}$ & $0.11 \%$ & $0.5 \%$ \\
\hline Fineness modulus & 2.5 & ---- \\
\hline
\end{tabular}

Table 5. Properties of coarse aggregate.

\begin{tabular}{|c|c|c|c|}
\hline Type of aggregate & Total density $\left(\mathbf{g} / \mathbf{c m}^{3}\right)$ & Bulk Specific Gravity & $\mathbf{S O}_{\mathbf{3}} \mathbf{( \% )}$ \\
\hline Crushed gravel & 1.54 & 2.7 & 0.01 \\
\hline
\end{tabular}

The properties of CFRP sheets shown in Table 6 were taken from the manufacturer's technical datasheet (Nitowrap FRC- Fosroc). The physical properties, yield stress, ultimate strength, and elongation of reinforcing steel bars are shown in Table 7. 
Table 6. Properties of CFRP sheets (Nitowrap FRC - Fosroc).

\begin{tabular}{|c|c|}
\hline Grade & FRC300 \\
\hline Fiber area weight $\left(\mathrm{g} / \mathrm{m}^{2}\right)$ & 300 \\
\hline Design thickness $(\mathrm{mm})$ & 0.167 \\
\hline Ultimate elongation & $1.5 \%$ \\
\hline Fiber density & $1.8 \mathrm{~g} / \mathrm{cm}^{3}$ \\
\hline Tensile strength $\left(\mathrm{kgf} / \mathrm{cm}^{2}\right)$ & 3480 \\
\hline Tensile E-modulus $\left(\mathrm{kgf} / \mathrm{cm}^{2}\right)$ & $2.30 \times 10^{5}$ \\
\hline
\end{tabular}

Table 7. Physical properties of reinforcing steel bars.

\begin{tabular}{|c|c|c|c|}
\hline Nominal bar diameter (mm) & Yield strength $\left(\mathrm{N} / \mathrm{mm}^{2}\right)$ & Ultimate strength $\left(\mathrm{N} / \mathrm{mm}^{2}\right)$ & Elongation \% \\
\hline$\phi 8$ & 345.3 & 499.6 & 16.5 \\
\hline$\phi 10$ & 616.6 & 681.0 & 10.0 \\
\hline$\phi 12$ & 629.2 & 701.2 & 10.6 \\
\hline
\end{tabular}

Finally, the physical properties of steel angles and battens are shown in Table 8. (ACI 211.1-91) [17] was adopted to calculate the proportions of concrete components for two normal strength concrete (NSC) mixes. The proportions of the concrete mixture are shown in Table 9.

Table 8. Physical properties of steel shapes.

\begin{tabular}{|c|c|c|c|}
\hline Shape & $\begin{array}{c}\text { Yield strength } \\
\left(\mathbf{N} / \mathbf{m m}^{\mathbf{2}}\right)\end{array}$ & $\begin{array}{c}\text { Ultimate strength } \\
\left(\mathbf{N} / \mathbf{m m}^{\mathbf{2}}\right)\end{array}$ & Elongation (\%) \\
\hline Steel angle $(\mathrm{L} 40 \times 40 \times 4 \mathrm{~mm})$ & 441 & 510 & 25.5 \\
\hline Steel battens $(40 \times 4 \mathrm{~mm})$ & 337 & 491 & 24.3 \\
\hline
\end{tabular}

Table 9. Mixture proportions.

\begin{tabular}{|c|c|c|}
\hline Mix component $\mathbf{( m}^{\mathbf{3}}$ ) & Quantity for $\boldsymbol{f}_{\boldsymbol{c}}^{\prime}=\mathbf{3 1 . 7} \mathbf{M P a}$ & Quantity for $\boldsymbol{f}_{\boldsymbol{c}}^{\prime}=\mathbf{2 4 . 2} \mathbf{M P a}$ \\
\hline Cement $(\mathrm{kg})$ & 400 & 278 \\
\hline Water (liter) & 160 & 158 \\
\hline Gravel $(\mathrm{kg})$ & 893 & 893 \\
\hline Sand $(\mathrm{kg})$ & 967 & 1095 \\
\hline FW52 (liter) & 5.7 & 3.5 \\
\hline
\end{tabular}

Test Set-up and Procedure: The test set-up is illustrated in Figure 3. The hydraulic compression machine used to test column specimens shown in Figure 2 was available at the structural laboratory at the College of Engineering at UOB. The load is applied by increasing the hydraulic press pressure incrementally with an equal load increment of $45.216 \mathrm{KN}$ till failure. The lateral and axial displacement of the columns were recorded by used dial gauges of Accuracy $(0.01 \mathrm{~mm})$. Two lateral dial gauges were located at the mid-height of the tested specimens, while the axial dial gauge was located on the top face of the lower plate of the compression machine.
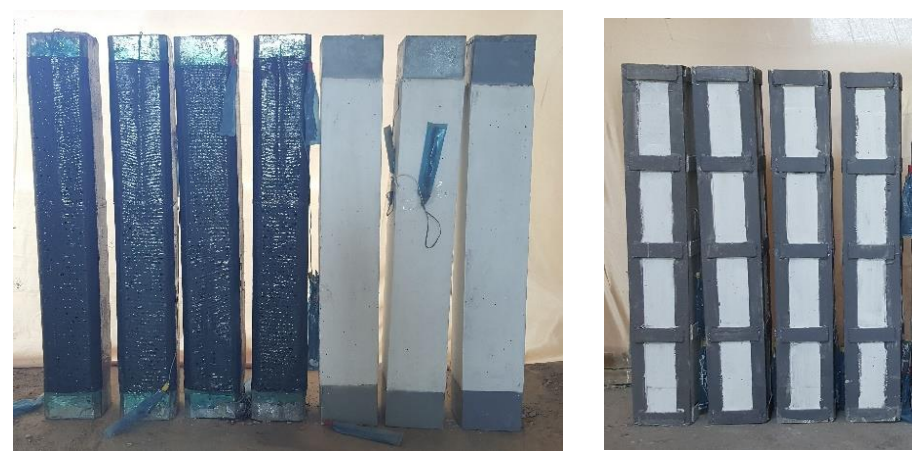

Figure 2. Column specimens. 

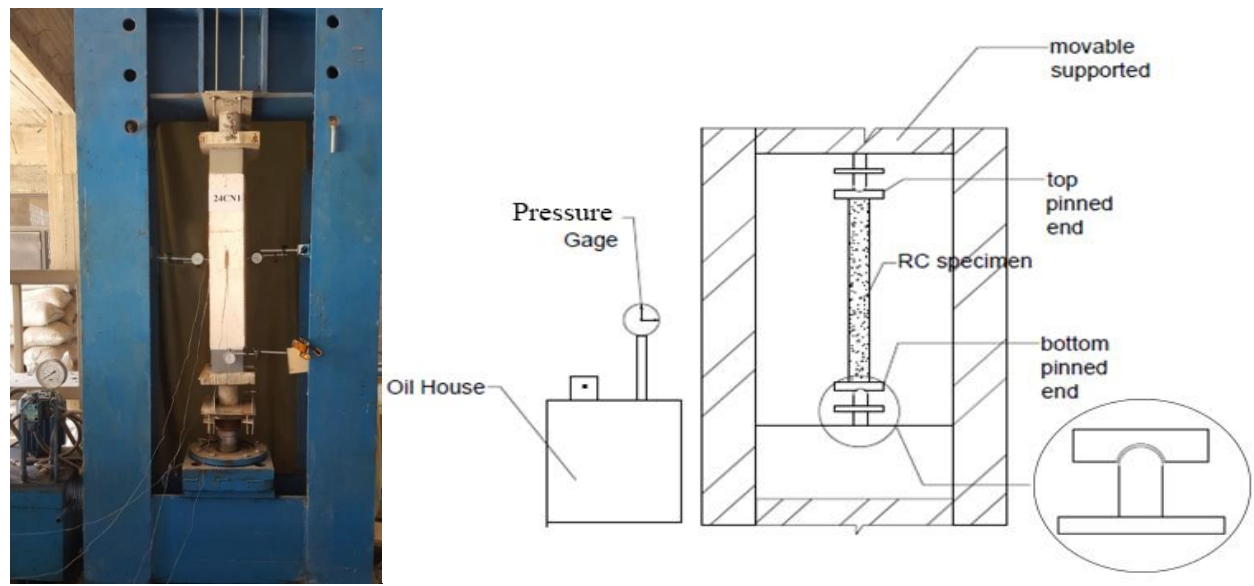

Figure 3. Testing set-up.

\section{Experimental Results and Discussions}

Column Behavior and Failure mode: Figure 4(a) illustrated the unstrengthened column specimens after testing. These columns were referred to as reference specimens since they are considered as the control specimens to study the effectiveness of the two strengthening techniques. It was observed that the failure mode of these columns was crushing at the top. This type of failure is the most common failure mode for short columns. Then, it was followed by buckling in the top region of longitudinal steel reinforcement. This is maybe a result of occurrences of high stresses at both ends of the column. Figure 4(b) and Figure 4(c) show the failure modes of columns strengthened with CFRP and SJ, respectively. The column specimens strengthened with CFRP exhibited a failure by CFRP rupture. The concrete cracks cannot be noticed inside the sheet during the test. However, a slight buckling in steel reinforcement was observed after failure as shown in Figure 4(b). The failure of SJ strengthened columns began with a crack occurring in the concrete. Then concrete crushing was taking place, followed by a slight buckling of the vertical steel angles. With increasing the load, concrete crushing continued, and a high buckle on the vertical steel angles was taking place.

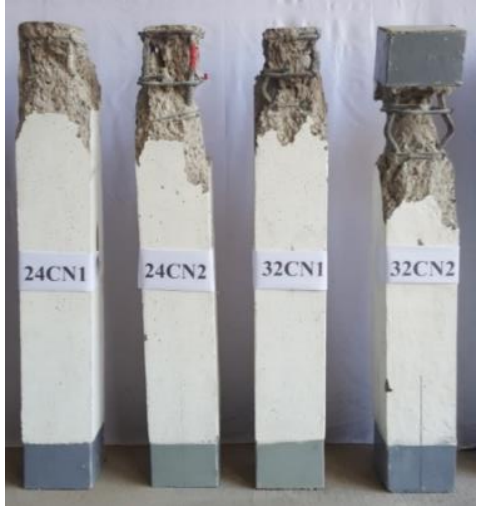

(a)

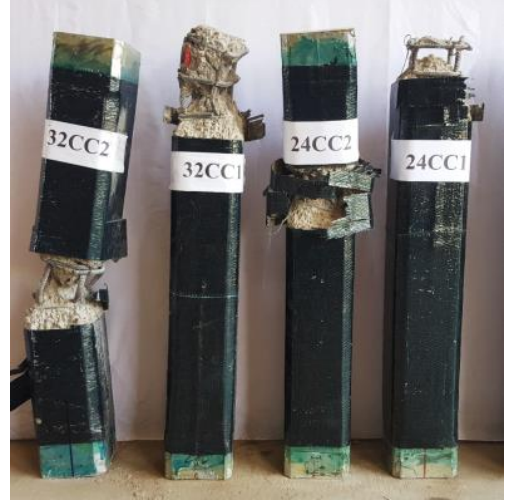

(b)

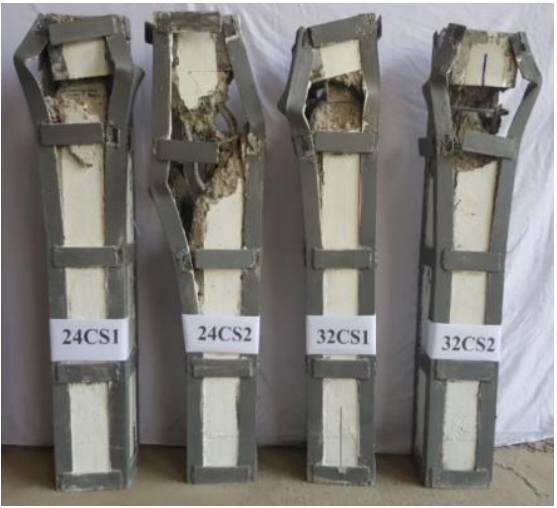

(c)

Figure 4. The failure modes of the column specimens: (a) reference, (b) CFRP strengthened, (c) SJ strengthened.

Load-Displacement Curves: Table 10 comprises the comprehensive results of all the tests conducted through this study. Obviously, the CFRP axial displacement reached a higher value than other strengthening techniques, which indicates the increase in ductility. This may be due to the effect of confinement of the CFRP wrapping during the dilation of the column. It is important to mention that the CFRP wrapping increased the concrete compressive strength in a range more than the SJ did. This is the reason to list the confined compressive strength $\mathrm{f}_{\mathrm{cc}}^{\prime}$. Only for columns strengthened with CFRP. However, SJ increased the load-carrying capacity higher than CFRP wrapping because the SJ is 
working with the concrete column as a composite member in which the vertical angles work as axial stiffness and the battens provide lateral support. The compressive strength of the column strengthened with CFRP was calculated using the equation adopted by ACI 440.2R-17 [18], as shown in Eq. 1.

$\mathrm{P}_{\mathrm{CC}}=0.85 \mathrm{f}^{\prime}{ }_{\mathrm{cc}} \mathrm{A}_{\mathrm{C}}+\mathrm{f}_{\mathrm{y}} \mathrm{A}_{\mathrm{S}}$

Where,

$\mathrm{P}_{\mathrm{cc}}=$ is the ultimate strength capacity of the column strengthened with CFRP,

$\mathrm{f}_{\mathrm{cc}}^{\prime}=$ is the confined compressive strength of concrete,

$\mathrm{A}_{\mathrm{c}}=$ is the area of concrete-section,

$\mathrm{A}_{\mathrm{s}}=$ is the area of steel reinforcement, and

$\mathrm{f}_{\mathrm{y}}=$ is the yield stress for steel reinforcement.

Figure 5 shows the load-axial displacement relationships for all types of columns. An improvement in the behavior of strengthened specimens concerning original columns can be seen. The load-carrying capacity of columns constructed with concrete compressive strength of $24 \mathrm{MPa}$ and reinforced by a steel ratio of $1 \%$ and strengthened with CFRP wrapping reached $768.67 \mathrm{KN}$. This increase in the carrying capacity represents 1.21 times compared with the unstrengthened reference column. While the same column reached $859.10 \mathrm{KN}$, i.e., 1.19 times when the steel reinforcement ratio was increased to $2 \%$. This slight decrease can be attributed to the effect of longitudinal steel bars in reducing the concrete share of compressive stress, which reduces the dilation and, in turn, limits the efficiency of the CFRP confinement. The above trend can also be seen in columns with compressive strength of $32 \mathrm{MPa}$. They resist ultimate loads of $949.54 \mathrm{kN}$ and $1039.97 \mathrm{kN}$ with steel reinforcement ratios of $1 \%$ and $2 \%$, respectively. Hence, the enhancement ratios were 1.17 and 1.15 when comparing with reference columns. On the other hand, the SJ technique enhanced the carrying load capacity for columns better than the CFRP wrapping technique. The ultimate load for the columns strengthened by SJ with compressive strength $24 \mathrm{MPa}$ reached about $1311.3 \mathrm{kN}$ for the column with a steel ratio $1 \%$ and $1446.9 \mathrm{kN}$ for the column with a steel reinforcement ratio of $2 \%$. This means that SJ enhanced the load-carrying capacity by 2.07 and 1.90 compared with reference columns. While SJ-strengthened columns with compressive strength $32 \mathrm{MPa}$ reached $1446.9 \mathrm{kN}$ and $1582.6 \mathrm{kN}$ for columns reinforced with steel reinforcement ratio 1 and $2 \%$, respectively. The calculated enhancement in carrying capacity was $1.78,1.75$ times the ones of reference columns. These results revealed a concept that the CFRP works better with low values of compressive strength, while the effect of the increase in the area of steel reinforcement was small compared with the effect of compressive strength.

In addition, it was noticed that the axial displacement in columns strengthened with CFRP was large compared with columns strengthened by SJ. This is maybe due to the effect of the confinement provided by CFRP wrapping, leading to increased ductility because the ratio of lateral confinement stress provided from the CFRP wrapping to the compressive strength of the column increased. However, the SJ technique enhanced the carrying load capacity for columns better than the CFRP wrapping technique. The ultimate load for the columns strengthened by SJ with compressive strength $24 \mathrm{MPa}$ reached about $1311.3 \mathrm{kN}$ for the column with steel ratio $1 \%$ and about $1446.9 \mathrm{kN}$ for the column with steel ratio $2 \%$. SJ enhanced the load-carrying capacity by 2.07 and 1.90 compared with reference columns. While SJ-strengthened columns with compressive strength $32 \mathrm{MPa}$ reached $1446.9 \mathrm{kN}$ and $1582.6 \mathrm{kN}$ for columns reinforced with steel reinforcement ratio $1 \%$ and $2 \%$, respectively. The calculated enhancement in carrying capacity was $1.78,1.75$ times the ones of reference columns. 

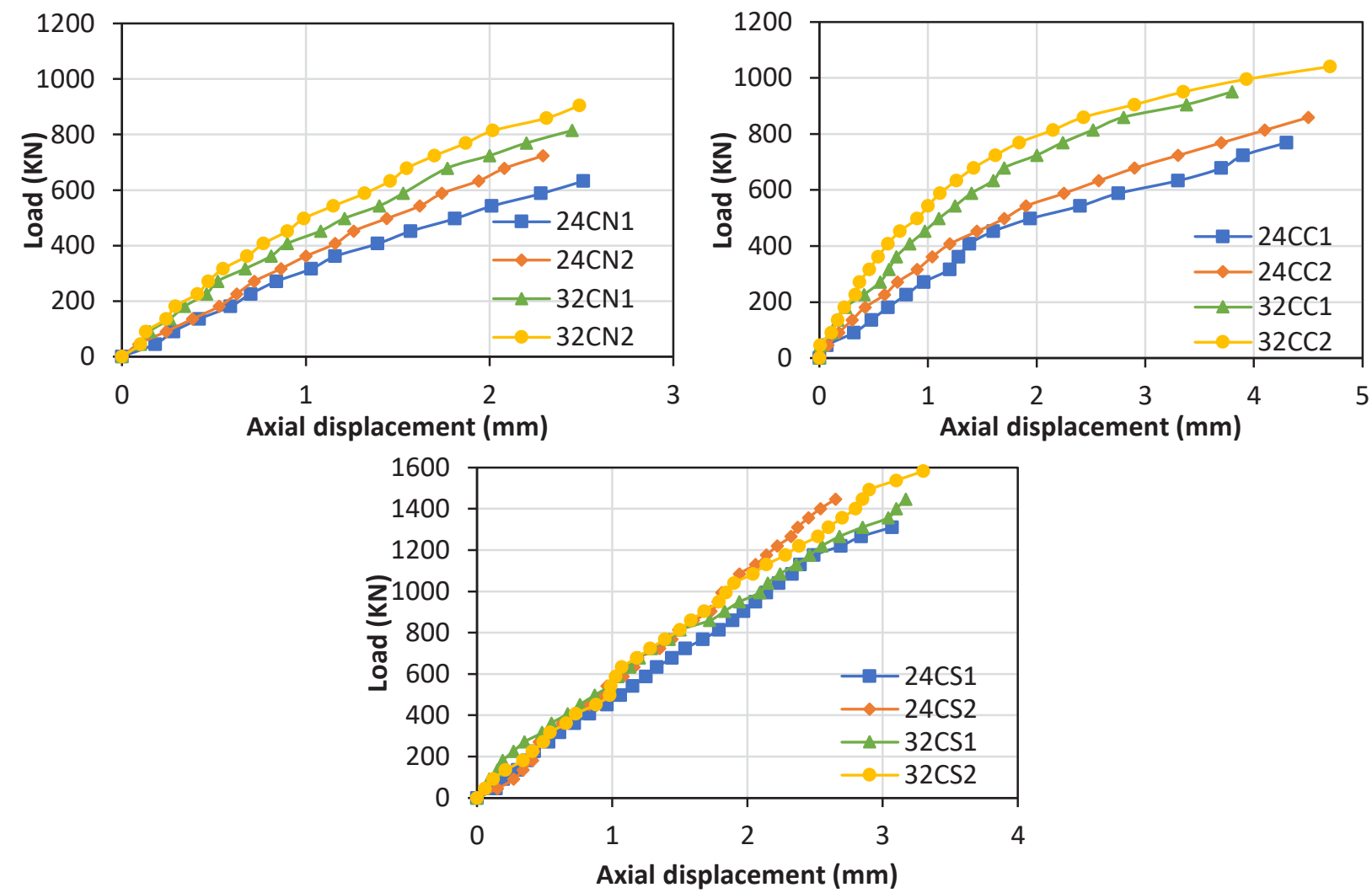

Figure 5. Load-axial displacement relationships.

Figure 6 shows the relationship between load and lateral deformation. Most of the columns fail with a small value of lateral deformation that means no considerable buckling occurred during the test because the column specimens were designed as short columns. Finally, Figure 7 illustrates the values of maximum load and axial deformation for all types of columns.
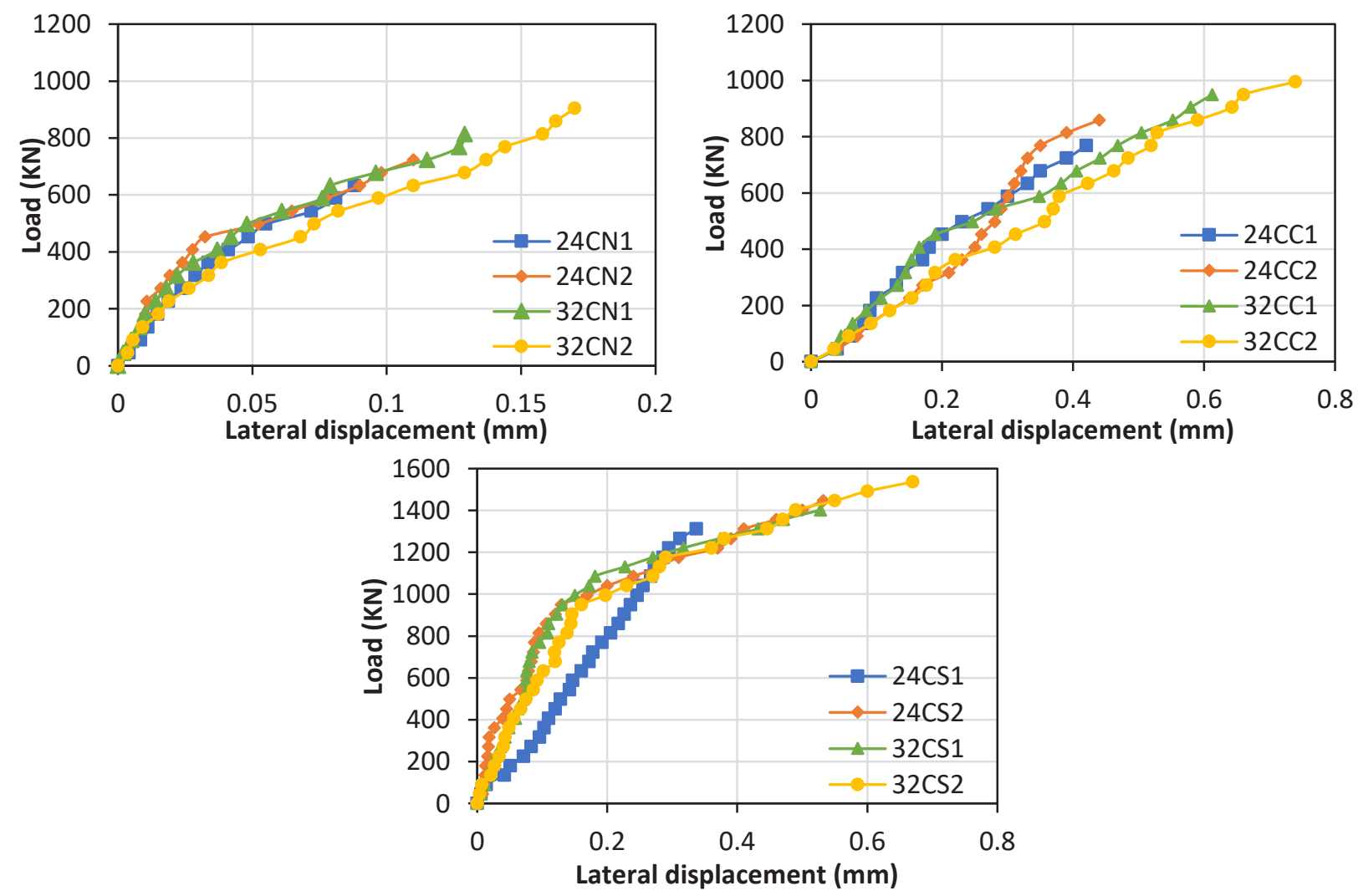

Figure 6. Load-lateral displacement relationships. 

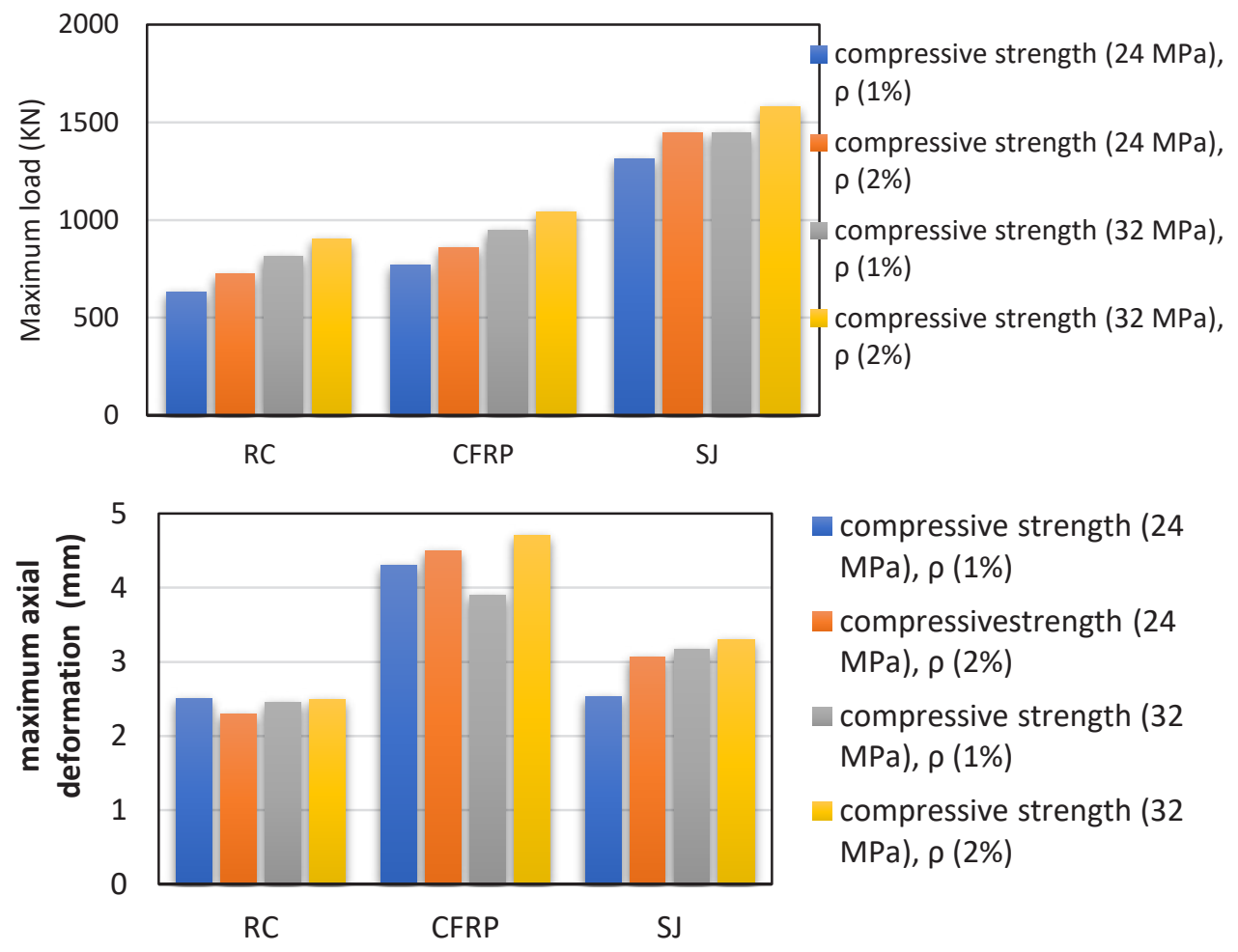

Figure 7. Maximum load and axial deformation for all types of columns.

Load-Strain Curves: The strains in steel and concrete were measured by means of strain gages. The results mounted using a special data logger program. Figure 8 shows the locations of strain gauges mounted on steel reinforcement, concrete, and steel jacket. Figure 9 illustrates the relationship between a load- strain in all tested columns. It was found that the ultimate strain value at the failure of columns strengthened with CFRP was relatively higher than the other columns. The steel angles were overpast the yield strain $(0.00221)$ that was obtained by the laboratory tests. The vertical angle in this research is connected with the head of the column, which means the load transfer directly to the angle of the jacket instead of transfer with friction which occurred in the case of partially strengthening with SJ; this is why the steel jacket reached yielding before column failure.

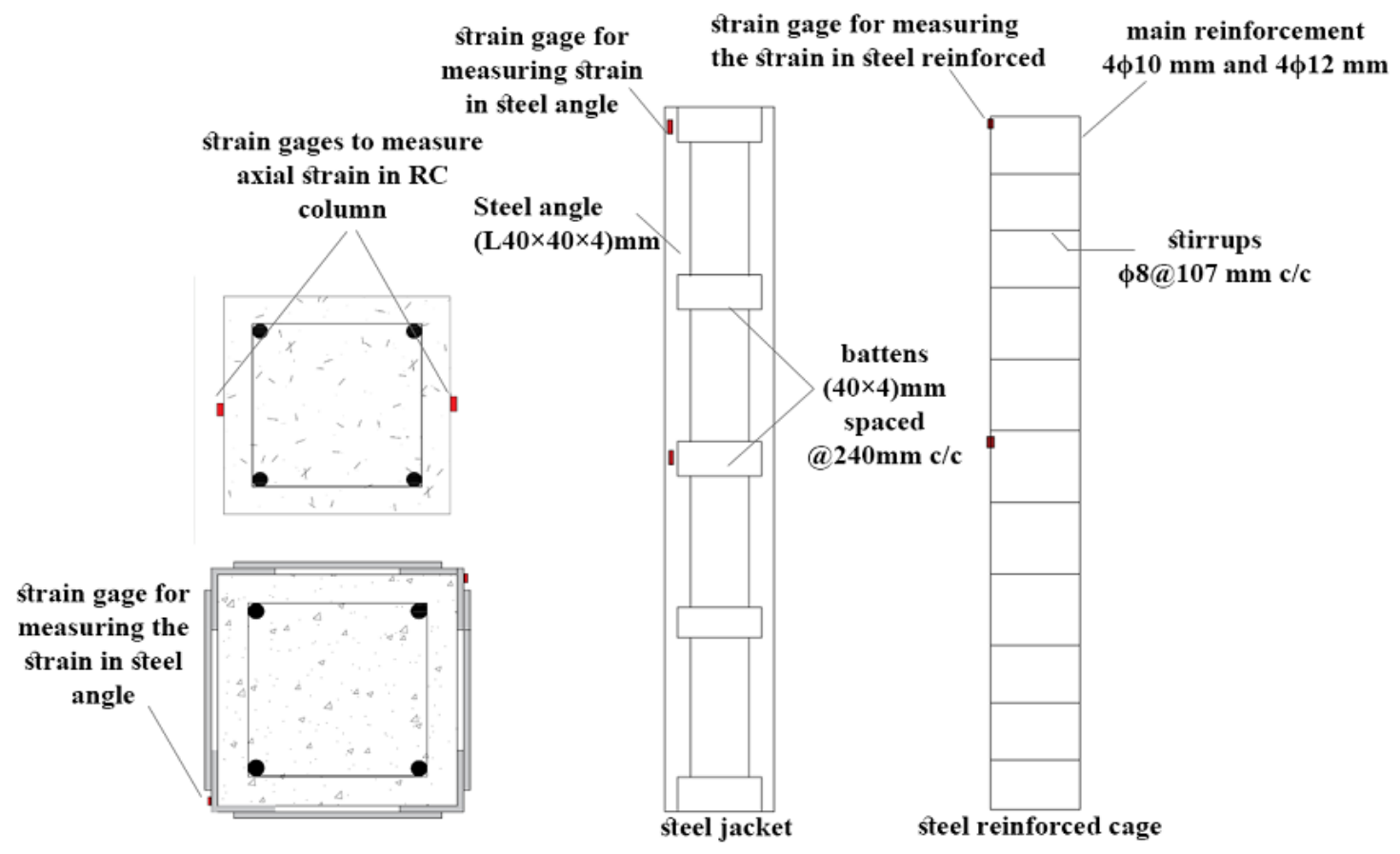

Figure 8. Strain gauges locations. 


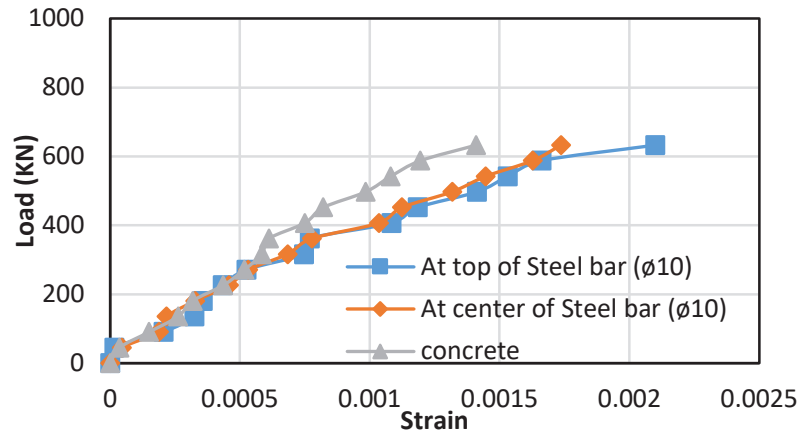

(a) $24 \mathrm{CN} 1$

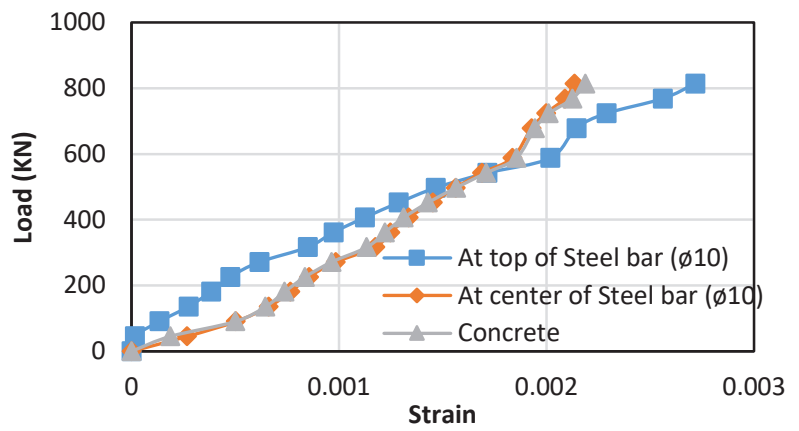

(c) $32 \mathrm{CN} 1$

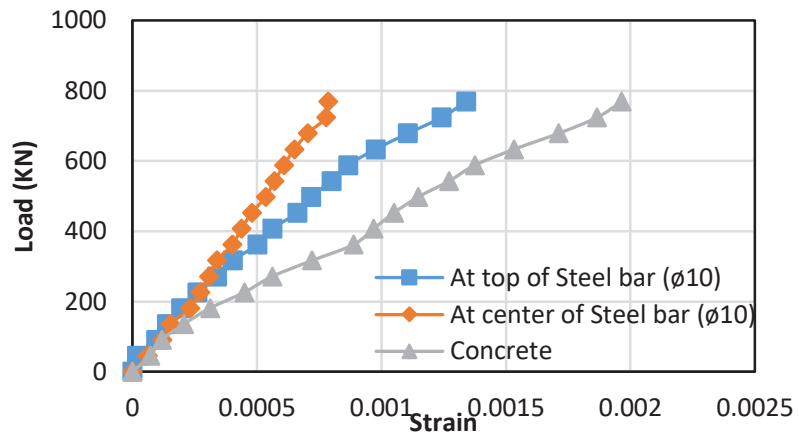

(e) $24 \mathrm{CC} 1$

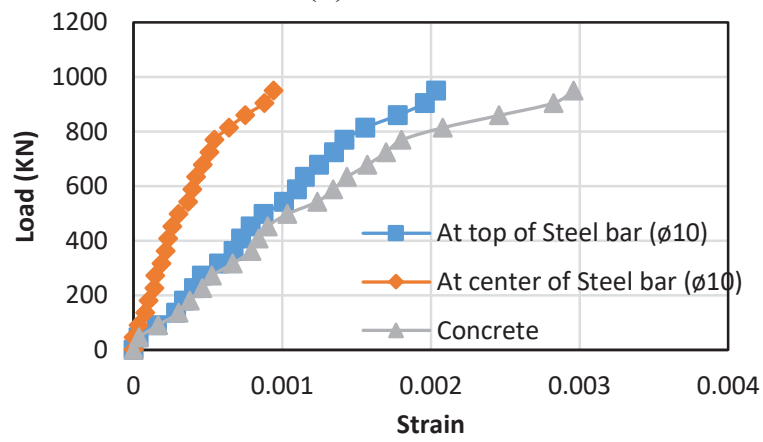

(g) $32 \mathrm{CC} 1$

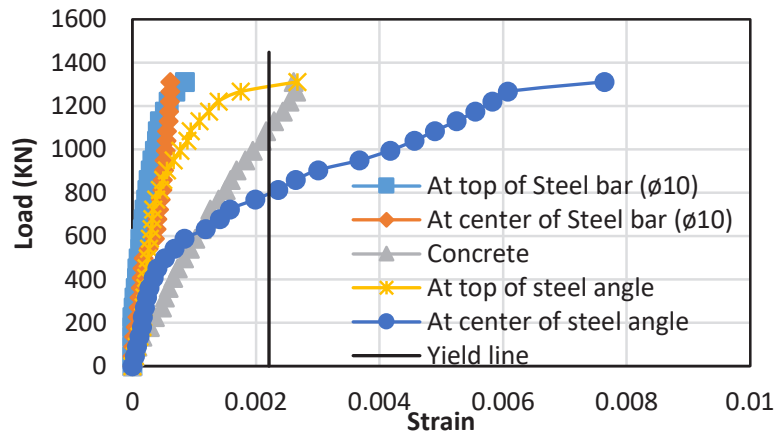

(i) $24 \mathrm{CS} 1$

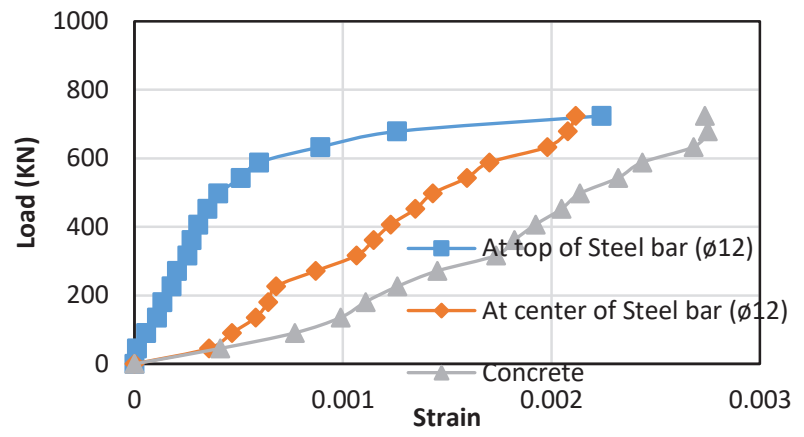

(b) $24 \mathrm{CN} 2$

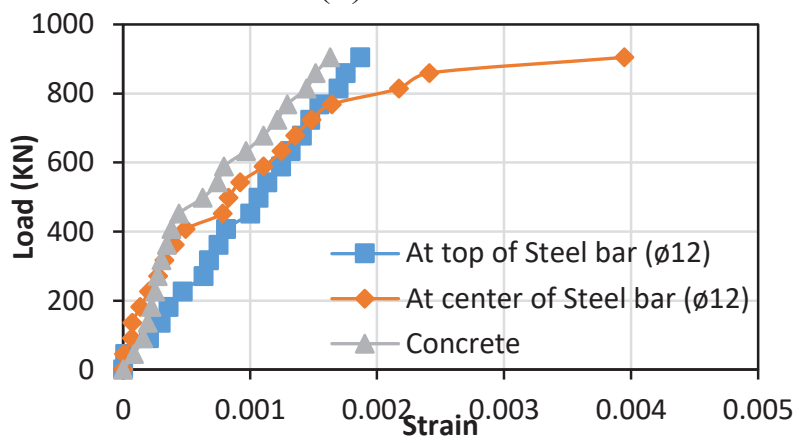

(d) $32 \mathrm{CN} 2$

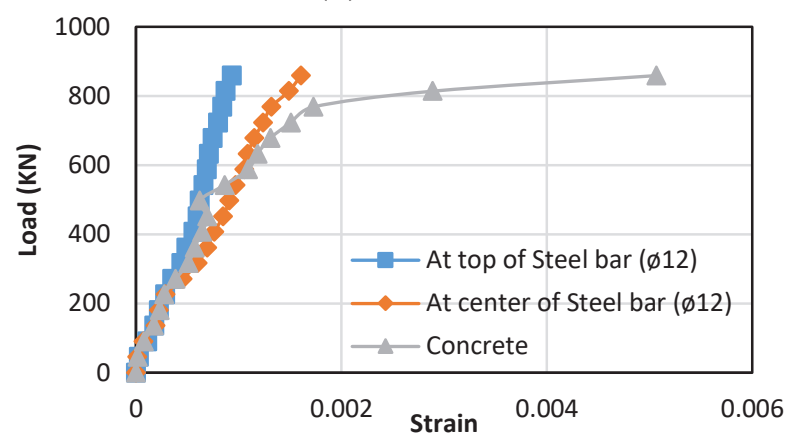

(f) $24 \mathrm{CC} 2$

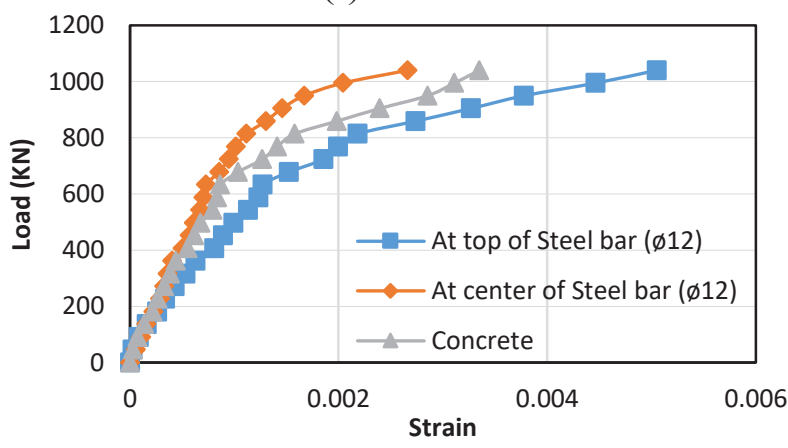

(h) $32 \mathrm{CC} 2$

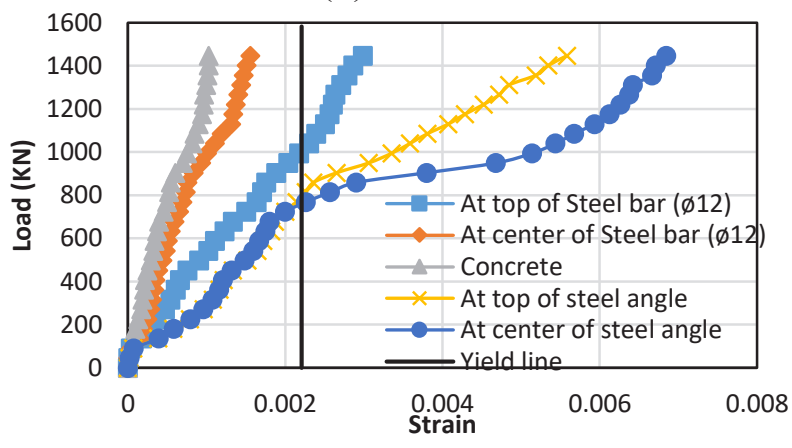

(j) $24 \mathrm{CS} 2$

Figure 9. Load-strain relationships. 


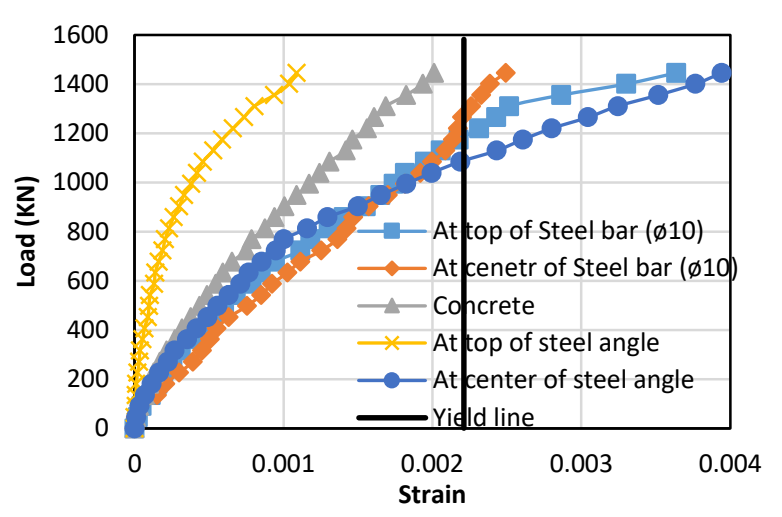

(k) $32 \mathrm{CS} 1$

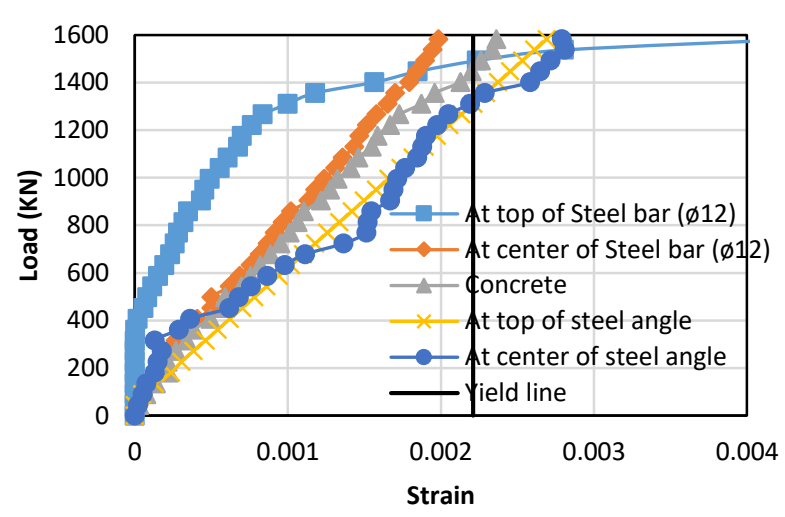

(1) $32 \mathrm{CS} 2$

Figure 9. Continued.

Table 10. The summary of results for all columns.

\begin{tabular}{|c|c|c|c|c|c|c|c|c|c|}
\hline $\begin{array}{l}\text { Column } \\
\text { code no. }\end{array}$ & $\begin{array}{l}\text { Strengthe } \\
\text { ning type }\end{array}$ & $\begin{array}{c}\mathbf{f}_{\mathbf{c}}^{\prime} \\
(\mathbf{M P a})\end{array}$ & $\begin{array}{c}\rho_{s} \\
(\%)\end{array}$ & $\begin{array}{c}\text { Ultimate } \\
\text { strength } \\
\text { (kN) }\end{array}$ & $\begin{array}{c}\text { Axial } \\
\text { deformation } \\
(\mathrm{mm})\end{array}$ & 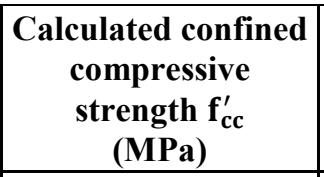 & $\begin{array}{c}\text { Load } \\
\text { Increment } \\
\text { ratio \% }\end{array}$ & $\frac{\mathbf{f}_{\mathbf{c c}}^{\prime}}{\mathbf{f}_{\mathbf{c}}^{\prime}}$ & $\begin{array}{l}\text { Failure } \\
\text { mode }\end{array}$ \\
\hline $24 \mathrm{CN} 1$ & Non & \multirow{3}{*}{24.2} & \multirow{3}{*}{1.4} & 633.02 & 2.51 & - & - & - & Crushing \\
\hline $24 \mathrm{CC} 1$ & CFRP & & & 768.67 & 4.30 & 31.5 & 1.21 & 1.30 & $\begin{array}{c}\text { Rupture of } \\
\text { CFRP }\end{array}$ \\
\hline $24 \mathrm{CS} 1$ & SJ & & & 1311.30 & 2.53 & - & 2.07 & - & $\begin{array}{c}\text { Total } \\
\text { buckling }\end{array}$ \\
\hline $24 \mathrm{CN} 2$ & Non & \multirow{3}{*}{24.2} & \multirow{3}{*}{2} & 723.46 & 2.30 & - & - & - & Crushing \\
\hline $24 \mathrm{CC} 2$ & CFRP & & & 859.10 & 4.50 & 31.8 & 1.19 & 1.31 & $\begin{array}{c}\text { Rupture of } \\
\text { CFRP }\end{array}$ \\
\hline $24 \mathrm{CS} 2$ & SJ & & & 1446.90 & 3.07 & - & 1.90 & - & $\begin{array}{c}\text { Total } \\
\text { buckling }\end{array}$ \\
\hline $32 \mathrm{CN} 1$ & Non & \multirow{3}{*}{32.7} & \multirow{3}{*}{1.4} & 813.89 & 2.45 & - & - & - & Crushing \\
\hline $32 \mathrm{CC} 1$ & CFRP & & & 949.54 & 3.90 & 41.4 & 1.17 & 1.26 & $\begin{array}{c}\text { Rupture of } \\
\text { CFRP }\end{array}$ \\
\hline $32 \mathrm{CS} 1$ & SJ & & & 1446.90 & 3.17 & - & 1.78 & - & $\begin{array}{c}\text { Total } \\
\text { buckling }\end{array}$ \\
\hline $32 \mathrm{CN} 2$ & Non & \multirow{3}{*}{32.7} & \multirow{3}{*}{2} & 904.32 & 2.50 & - & - & - & Crushing \\
\hline $32 \mathrm{CC} 2$ & CFRP & & & 1039.97 & 4.70 & 41.7 & 1.15 & 1.28 & $\begin{array}{c}\text { Rupture of } \\
\text { CFRP }\end{array}$ \\
\hline $32 \mathrm{CS} 2$ & SJ & & & 1582.60 & 3.30 & - & 1.75 & - & $\begin{array}{c}\text { Total } \\
\text { buckling }\end{array}$ \\
\hline
\end{tabular}

\section{Conclusions}

The following was concluded from the experimental studies presented in this paper:

- Both strengthening methods, CFRP wrapping, and SJ increased the load-carrying capacity when compared with the reference columns. The enhancement ratio, which ranged between (1.15 to 2.07) was found to be decreasing when increasing both steel reinforcement ratio and concrete compressive strength

- The SJ techniques enhanced the column carrying capacity more than the CFRP technique by about 1.65 and 1.52 for concrete with 24 and $32 \mathrm{MPa}$ compressive strength.

- The CFRP wrapping increased the ultimate concrete strain, increasing the column ductility higher than the SJ method.

- The axial deformation for columns strengthened with the CFRP technique increased when compared with original columns by 83.5 and $73.6 \%$ for concrete with 24 and $32 \mathrm{MPa}$ compressive strength, respectively. 
- The column specimens strengthened with CFRP exhibited a failure by CFRP rupture, while the failure of SJ strengthened columns began with a crack occurring in the concrete, which developed to concrete crushing, then was followed by a slight buckling of the vertical steel angles.

- Finally, further studies are needed to examine the structural performance of these types of columns under various loading conditions.

\section{References}

[1] Abdelwahed, B., 2019. A review on building progressive collapse, survey and discussion. Case Studies in Construction Materials, 11, p.e00264.

[2] Abdualrahman, S.Q. and Al-Zuhairi, A.H., 2020, July. Structural Performance of Slender RC Columns with Cross and Square-Shaped under Compression Load. In IOP Conference Series: Materials Science and Engineering (Vol. 881, No. 1, p. 012040). IOP Publishing.

[3] Abdualrahman, S.Q. and Al-Zuhairi, A.H., 2020. A Comparative Study of the Performance of Slender Reinforced Concrete Columns with Different Cross-Sectional Shapes. Fibers, 8(6), p.35.

[4] Naqi, A.W. and Al-zuhairi, A.H., 2020. Nonlinear Finite Element Analysis of RCMD Beams with Large Circular Opening Strengthened with CFRP Material. Journal of Engineering, 26(11), pp.170-183.

[5] Mazzotti, C., Bilotta, A., Carloni, C., Ceroni, F., D’Antino, T., Nigro, E. and Pellegrino, C., 2016. Bond between EBR FRP and concrete. In Design procedures for the use of composites in strengthening of reinforced concrete structures (pp. 39-96). Springer, Dordrecht.

[6] Etman, E.E. and Khalil, A.A., 2003. Effect of Corner Radius on the Behavior of Strengthened RC Columns with Different Heights. In AICSGES, Fifth Alexandria International Conference on Structural and Geotechnical Engineering, Alexandria, Egypt, DEC., pp RC (pp. 345-360).

[7] El-Kurdi, A., Khoury, S., Aly Eldarwish, A.K. and Morsy, A., 2003, December. Behavior of axially loaded columns strengthened with carbon fiber reinforced polymers. In Proceeding of Alexandria International Conference for Structural and Geotechnical Engineering, Alexandria, Egypt.

[8] Montaser, W., El-Kateb, M. and Nabil, M., Experimental and Analytical Study of Square Columns Strengthed and Repaired Using Cfrp Sheets Partially and Fully Wrapped.

[9] Al-Khafaji, H.L., 2016. Experimental Investigation of CFRP Wrapped Square Non-Ductile Reinforced Concrete Columns.

[10] Tarabia, A.M. and Albakry, H.F., 2014. Strengthening of RC columns by steel angles and strips. Alexandria Engineering Journal, 53(3), pp.615-626.

[11] Belal, M.F., Mohamed, H.M. and Morad, S.A., 2015. Behavior of reinforced concrete columns strengthened by steel jacket. HBRC Journal, 11(2), pp.201-212.

[12] Farjana, A., 2018. Behaviour and strength of steel jacketed RC columns under concentric axial load. [13] Akter, F. and Begum, M., 2021. Behaviour of the partial steel-jacketed preloaded RC columns under concentric axial load. Asian Journal of Civil Engineering, 22(4), pp.713-726.

[14] Farhangi, V. and Karakouzian, M., 2020. Effect of fiber reinforced polymer tubes filled with recycled materials and concrete on structural capacity of pile foundations. Applied Sciences, 10(5), p.1554.

[15] Specification, I.S., 1984. No. 5/1984, Portland Cement. Central Organization for Standardization \& Quality Control (COSQC), Baghdad, Iraq.

[16] Nasr, M.S., Shubbar, A.A., Abed, Z.A.A.R. and Ibrahim, M.S., 2020. Properties of eco-friendly cement mortar contained recycled materials from different sources. Journal of Building Engineering, 31, p.101444.

[17] Dixon, D.E., Prestrera, J.R., Burg, G.R., Chairman, S.A., Abdun-Nur, E.A., Barton, S.G., Bell, L.W., Blas Jr, S.J., Carrasquillo, R.L., Carrasquillo, P.M. and Carter, A.C., 1991. Standard Practice for Selecting Proportions for Normal, Heavyweight, and Mass Concrete (ACI 211.191). 
[18] de Waal, L., Fernando, D., Cork, R. and Foote, J., 2017. FRP strengthening of 60 year old prestressed concrete bridge deck units. Engineering Structures, 143, pp.346-357. 